\section{Ornamental Cherry Tolerance of Flooding and Phytophthora Root Rot}

\author{
K.A. Jacobs ${ }^{1}$ and G.R. Johnson ${ }^{2}$ \\ U.S. Department of Agriculture, Floral and Nursery Plants Research Unit, \\ U.S. National Arboretum, Washington, DC 20002
}

Additional index words. Prunus spp., Phytophthora cryptogea, photosynthesis

\begin{abstract}
Seedlings of eight Prunus taxa were evaluated for variation in susceptibility to a single, 4- or 5-day flooding period and root rot caused by Phytophthora cryptogea Pethybr. \& Lafferty. Survival, plant defoliation, disease severity index, root necrosis, and net photosynthesis indicated that the combination of flooding and pathogen was significantly more severe to all taxa than either individual treatment. Most response variables reflected early plant dysfunction but were not correlated with long-term survival. Long-term survival was $70 \%$ in the combination treatment compared to $99 \%$ in the control group. Flooding injured seedlings more than the pathogen in most taxa. Taxa differed only slightly in tolerance to the treatments, as measured by survival rate. Prunus takesimensis Nakai had the highest survival rate of $100 \%$ and along with $P$. mahaleb L. and $P$. yedoensis Matsum. showed some tolerance to flooding and the pathogen. Prunus sargentii Rehd. had the lowest survival rate of $81 \%$ and appeared to be least tolerant to the pathogen.
\end{abstract}

Prunus species have shown varying tolerance to flooding injury, ranging from sensitive Mahaleb cherry $(P$. mahaleb $)$ and apricot $(P$. armeniaca L.) to tolerant European plum $(P$. domestica L.) and Japanese bush cherry $(P$. japonica Thunb.) (Mizutani et al., 1979; Rowe and Beardsell, 1973; Rowe and Catlin, 1971). Ranney (1994) found a range of flood tolerance in ornamental Prunus and ranked Yoshino $(P$. yedoensis), Sargent $(P$. sargentii), and 'Okame' cherry ( $P$. incisa Thunb. $\times P$. cerasoides var. campanulata Maxim. 'Okame') intermediate to the more tolerant Mazzard cherry ( $P$. avium L. 'F-12/1') and Newport plum $\{[(P$. salicina Lindl. $) \times(P$. americana Marsh. $\times$ P. nigra Ait.)] $\times$ P. cerasifera Ehrh.\} 'Newport' and the more susceptible Carolina cherry laurel $[P$. caroliniana (Mill.) Ait.].

Poor survival of trees in flooded conditions is associated with a lack of morphological, physiological, and anatomical adaptation to reduced oxygen (Kawase, 1981), but flooding also can increase the susceptibility of tree roots to soilborne pathogens (Stolzy and Sojka, 1984). The incidence of phytophthora root rot increases dramatically in Prunus spp. grown for fruit production when plants are flooded simultaneously or immediately after infection

Received for publication 23 Oct. 1995. Accepted for publication 7 May 1996. We thank Ruth Dix, John Knowlton, III, Johann Klodzen, and George Warholic for technical assistance and S.M. Mircetich for providing the Phytophthora isolates. Many thanks to F.S. Santamour, Jr., T.G. Ranney, and Ruth Dix for reviewing the manuscript. The cost of publishing this paper was defrayed in part by the payment of page charges. Under postal regulations, this paper therefore must be hereby marked advertisement solely to indicate this fact.

${ }^{1}$ Current address: Morton Arboretum, Route 53, Lisle, IL 60532.

${ }^{2}$ Current address: U.S. Dept. of Agriculture Forest Service, Pacific Northwest Research Station, Forest Sciences Laboratory, 3200 Jefferson Way, Corvallis, OR 97330.
(Wilcox and Mircetich, 1985a). Whether a synergistic relationship exists between flooding and phytophthora root rot in ornamental cherries is unknown. This information would be useful for selecting parent material in breeding programs, and selecting species and cultivars for placement in potentially stressful landscapes.

The objectives of this research were to assess potential variation in susceptibility among the Prunus populations used in the ornamental shrub breeding program at the U.S. National Arboretum to a combination of flooding and Phytophthora soil infestation.

\section{Materials and Methods}

Six- to 12-month-old seedlings of eight Prunus taxa were evaluated for susceptibility to flooding and phytophthora root rot. Seven taxa were grown from open-pollinated seed collected from four maternal species: $P$. takesimensis, $P$. verecunda, $P$. incisa, $P$. yedoensis; and two hybrids (HY): 5111 [ $(P$. incisa $\times P$. cerasoides var. campanulata $) \times P$. cerasoides var. campanulata $]$ and 5118 [ $(P$. nipponica var. kurilensis $\times$ P. cerasoides var. campanulata) $\times$ P. incisa]. One-year-old seedlings of $P$. sargentii and $P$. mahaleb were obtained from commercial sources (Princeton Nursery and Lawyers Nursery, respectively). Sixty seedlings of each taxon were evaluated, except for $P$. takesimensis (20 seedlings) and HY 5111 (40 seedlings). The experiment was designed as a split plot, with the flooding, Phytophthora, and combination treatments as main plots and taxon as the subplot. The treatments were applied in a $2 \times 2$ factorial design with the factors as flooded or not flooded and with or without Phytophthora. The experiment was repeated three times, and each repetition was considered a block in the analyses.

The experiment was conducted outdoors by transferring each seedling to a 2.3 -L container and placing the containers in plastic pools. A separate pool was used for each of the four treatments, and wood frames with plastic and shadecloth were placed over each pool to moderate temperatures and exclude rain. The temperature inside two containers per treatment was monitored regularly.

Phytophthora cryptogea was chosen as the pathogen over other Phytophthora spp. because of its virulence on sweet cherry $(P$. avium) (S.M. Mircetich, Univ. of California, Davis, personal communication) and because a preliminary study indicated that $P$. cryptogea was slightly more virulent than $P$. cambivora (Petri) Buisman on several ornamental Prunus taxa. The strain used was obtained from California (courtesy of S.M. Mircetich) and strict confinement procedures were used to prevent spread of the pathogen. Inoculum was prepared according to methods of Mircetich and Matheron (1976), in which autoclaved vermiculite and barley (Hordeum vulgare L.) seeds were inoculated with mycelial agar plugs of the pathogen. After 3 weeks, the colonized vermiculite was mixed 1:10 (v/v) with pasteurized Metro Mix 500 (Scotts-Sierra, Marysville, Ohio). Seedlings in the pathogen and combination treatments were transplanted into 2.3-L containers filled with the $P$. cryptogea-infested medium and immediately flooded for $2 \mathrm{~h}$ to encourage zoospore release. All other seedlings were transplanted into pasteurized Metro Mix 500. Control plants were flooded for $2 \mathrm{~h}$ as was done in the pathogen treatment, and plants in the flooded and combination treatments were flooded for either 4 or 5 days. Preliminary tests indicated that flooding for <4 days did not significantly stress plants; thus, 5 days of flooding was tried in the first block. Because seedlings were nearly defoliated in the first block, a 4-day flooding period was used in the second and third blocks to stress plants but avoid complete defoliation and plant death. The entire root system was inundated during flooding by filling the plastic pools with water. Plants were transferred to empty pools at the end of flooding and watered subsequently as needed. At the end of 4 weeks, three plants of each taxon were harvested from each treatment and root systems were evaluated as described below.

Root systems of harvested plants were washed and rated visually for the percentage of the root system exhibiting dark brown to black necrosis. Each root sample was then blotted dry and weighed to determine fresh weight. Roots from plants subjected to the Phytophthora and combination treatments were plated onto the semi-selective medium PARP (Kannwisher and Mitchell, 1978) to confirm colonization by $P$. cryptogea had occurred.

The response variables measured were: disease severity index (DSI; 1 = asymptomatic, $4=$ complete defoliation or leaf necrosis) 1,2 , and 4 weeks after flooding was started; percent defoliation 1 and 4 weeks after flooding was started; percent root necrosis and root fresh weight 4 weeks after flooding was started; survival following cold storage at $10^{\circ} \mathrm{C}$ for 3 months; net photosynthesis rate $\left(\mathrm{P}_{\mathrm{n}}\right)$ before, during, and after flooding. 
Six plants of each taxon (two plants per block) were chosen at random from each treatment to monitor $P_{n}$, and one leaf per plant (fourth to sixth position) was measured at each sampling date. When a plant was completely defoliated, a zero was recorded as the $\mathrm{P}_{\mathrm{n}}$ value and another plant was measured. Rate of photosynthesis was measured for $25 \mathrm{~s}$ and calculated per unit leaf area using a portable gas exchange system (LI-COR, Lincoln, Neb.). Readings were made only on sunny days between 0700 and $1000 \mathrm{HR}$.

Differences in the response variables due to the treatments, taxon differences, and block effects were analyzed using the Generalized Linear Model Procedure (SAS Institute, 1990).

\section{Results and Discussion}

Variation in response of the eight Prunus taxa was caused primarily by flooding and pathogen effects, although a taxon effect was detected for some response variables (Table 1). Root fresh weight was the only response variable affected more by taxon differences than by flooding and pathogen effects, as indicated by a comparatively large taxon effect mean square (data not shown). Flooding had a greater impact than the pathogen on host responses, as indicated by the large flooding effect mean squares (data not shown), and the comparisons of treatment means (Table 2). A minor block effect was detected, undoubtedly due to the more severe conditions of the first block in which the flooding period was 1 day longer and the average temperature was $33^{\circ} \mathrm{C}$, compared to 30 and $28^{\circ} \mathrm{C}$ in blocks 2 and 3 , respectively. The severity of the treatments was ranked the same in all three blocks, regardless of the presence of a block effect.

The combination of flooding and $P$. cryptogea nearly always caused the most severe host response (Table 2) and acted in an additive or synergistic fashion as evidenced by the lack of a flooding $\times$ Phytophthora interaction effect for most variables (Table 1). A third-order interaction effect was detected for some responses, but minuscule mean square values were associated with these effects. The combination treatment resulted in the lowest survival rate, lowest root fresh weight, and lowest $P_{n}$ of all treatments, while defoliation and DSI were highest.
Flooding affected all response variables significantly $(P \leq 0.05)$, except diameter growth (Table 2). Nonetheless, $84 \%$ of flooded plants still survived, suggesting that the taxa could tolerate a single, short-term flooding event relatively well. Longer or repeated flooding periods reduce survival of ornamental Prunus. For example, survival rates of many of the same taxa examined in the present study were between $0 \%$ and $22 \%$ in a preliminary study in which seedlings were flooded continuously for 8 days. Ranney (1994) reported survival rates $20 \%$ lower than in our study for 1 - to 2 year-old $P$. yedoensis and $P$. sargentii plants exposed to continuous, incremental flooding for 7 weeks.

The pathogen had an effect on most response variables, but it did not affect survival, the trait of ultimate importance (Table 2). Survival was significantly reduced in plants exposed to P. cryptogea only if they were simultaneously flooded. Wicks and Lee (1985) reported similar findings for almond $[P$. dulcis (Mill.) D. Webb] infected with P. cambivora (Petri) Buisman. Wilcox and Mircetich (1985b) found that several flooding events were needed before root necrosis and mortality could be detected in $P$. mahaleb seedlings infected by $P$. cryptogea. In our study, root infection and colonization by $P$. cryptogea was confirmed by reisolating the fungus from roots, yet a relatively low level of disease was measured. The low disease level may have been due to the short duration of flooding and the fact that many seedlings had large root systems that were probably colonized only partially by the fungus. Repeated or longer flooding events would be expected to result in higher disease levels than those we measured.

Initial plant height significantly influenced several response variables (Table 1), but it had the greatest impact on root fresh weight according to the mean squares (data not shown). Prunus sargentii, $P$. takesimensis, and $P$. mahale $b$ were the tallest taxa, and not surprisingly, they had the highest root fresh weights (Table 3). The relationship between initial plant height and other response variables was less consistent, but some of the data suggest that the taller plants suffered more than shorter plants. For example, two of the three tallest taxa, $P$. sargentii and $P$. takesimensis, had the highest percent defoliation (Table 3 ) and the lowest $\mathrm{P}_{\mathrm{n}}$ during flooding (Table 4). Prunus sargentii also had the highest DSI at 1,2, and 4 weeks and the most root necrosis (Table 3 ). The potential influence of initial plant height on host responses, especially root responses to flooding and Phytophthora spp., should be considered in future studies.

The taxa did not rank consistently among response variables for tolerance to the treatments; therefore, survival was used as the primary criterion of tolerance. Survival was quite high in all taxa, but some variation existed (Table 3). Prunus takesimensis had the highest survival rate across all treatments, closely followed by $P$. mahaleb and $P$. yedoensis. The same three taxa ranked similarly in the combination treatment. The other five taxa had survival rates between $81 \%$ and $84 \%$ across all treatments, and $P$. sargentii had the lowest survival rate (Table 3).

Survival was not correlated with any other response variable; instead, most responses appeared to indicate short-term plant dysfunction and loss of vigor. These responses might eventually affect survival since diminished vigor due to flooding can enhance susceptibility of seedlings and trees to subsequent environmental stress and disease (Frye and Grosse, 1992). The lack of association between survival and other responses was exemplified in several taxa. For example, $P$. takesimensis showed an immediate drop in $\mathrm{P}_{\mathrm{n}}$ to $11 \%$ to $22 \%$ of the control (Table 4 ), had much defoliation, and was given a high DSI 1 week after flooding (Table 3). Taken together, this suggests that it was less tolerant of flooding and root rot injury than most other taxa. Nevertheless, all $P$. takesimensis seedlings survived. Perhaps early defoliation and reduced $P_{n}$ are mechanisms of survival for this taxon, which is adapted to riparian habitats in its native Korea. Further evaluation of $P$. takesimensis is needed since we examined only 20 seedlings.

Prunus mahaleb had the second highest survival rate across all treatments and grew significantly more than any other taxon. However, unlike $P$. takesimensis, it had the lowest defoliation rate and maintained a low DSI throughout the experiment (Table 3). Prunus mahaleb is highly susceptible to flooding and phytophthora root rot under conditions of repeated or long-term flooding (Wilcox and Mircetich, 1985a, 1985b). The comparatively

Table 1. Analysis of variance for data from Prunus experiment with initial height as a covariate. Only significant effects and response variables are included.

\begin{tabular}{|c|c|c|c|c|c|c|c|c|c|c|c|c|c|}
\hline Source & $\mathrm{df}$ & $\begin{array}{c}\begin{array}{c}\text { Sur- } \\
\text { vival }\end{array} \\
\end{array}$ & DSI $1^{z}$ & $\mathrm{DSI}^{\mathrm{z}}$ & DSI4 $^{z}$ & $\begin{array}{c}\text { Defoli- } \\
\text { tion }\end{array}$ & $\begin{array}{c}\text { Root } \\
\text { necrosis }\end{array}$ & $\begin{array}{c}\text { Root } \\
\text { wt }\end{array}$ & $\begin{array}{c}\mathrm{Ht} \\
\text { growth }\end{array}$ & $\begin{array}{c}\text { Diam } \\
\text { growth }\end{array}$ & $P_{n} f^{y}$ & $P_{n} 1^{y}$ & $P_{n} 2^{y}$ \\
\hline Flood (F) & 1 & * & *** & *** & $*$ & ** & *** & * & * & & $*$ & $* *$ & $* *$ \\
\hline Phytophthora (P) & 1 & & $* *$ & ** & & $* *$ & $*$ & & & & ** & $* *$ & \\
\hline Block (B) & 2 & & & & & & $*$ & & $*$ & & & $*$ & ** \\
\hline $\mathrm{F} \times \mathrm{P}$ & 1 & & & & & & & & & & * & & $*$ \\
\hline Таха $(\mathrm{T})$ & 7 & & $* *$ & *** & ** & ** & ** & $* *$ & $* *$ & & & * & \\
\hline $\mathrm{T} \times \mathrm{F}$ & 7 & & $* *$ & ** & & $*$ & & & & & & & \\
\hline $\mathrm{T} \times \mathrm{P}$ & 7 & & & & & & & $* *$ & & & & & \\
\hline $\mathrm{T} \times \mathrm{B} \times$ treatment $^{\mathrm{x}}$ & 44 & & & & $*$ & & $* *$ & $*$ & $* *$ & ** & $*$ & * & \\
\hline Covariate height & 1 & & & * & & * & & ** & $*$ & ** & * & & \\
\hline Error $^{\mathrm{w}}$ & & 0.09 & 0.30 & 0.37 & 0.39 & 677 & 225 & 244 & 16.8 & 0.16 & 6.5 & 10.7 & 16.3 \\
\hline
\end{tabular}

${ }^{2}$ Disease severity index (DSI) 1, 2, and 4 weeks after the onset of flooding; $1=$ asymptomatic, $4=$ complete defoliation or leaf necrosis.

${ }^{y}$ Net photosynthesis during flooding $\left(\mathrm{P}_{\mathrm{n}} \mathrm{fl}\right), 1$ week $\left(\mathrm{P}_{\mathrm{n}} 1\right)$, and 2 weeks $\left(\mathrm{P}_{\mathrm{n}} 2\right)$ after flooding ceased.

${ }^{x}$ Flood and Phytophthora treatment effects were combined for simplicity.

"Degrees of freedom varied between 203 and 301 due to incomplete representation of taxa for some response variables.

*,** Significant at $P \leq 0.05$ or 0.01 , respectively. 
Table 2. Mean responses of all Prunus taxa to flooding, Phytophthora, and combination treatments. ${ }^{2}$

\begin{tabular}{lcccc}
\hline \hline & \multicolumn{3}{c}{ Treatment } \\
\cline { 2 - 5 } Variable & Control & Phytophthora & Flood & Combination \\
\hline Survival (\%) & $99 \mathrm{a}$ & $96 \mathrm{a}$ & $84 \mathrm{~b}$ & $76 \mathrm{~b}$ \\
Defoliation (\%) & $10 \mathrm{c}$ & $51 \mathrm{~b}$ & $77 \mathrm{a}$ & $90 \mathrm{a}$ \\
DSI 1 & $1.2 \mathrm{~d}$ & $2.4 \mathrm{c}$ & $3.1 \mathrm{~b}$ & $3.6 \mathrm{a}$ \\
DSI 2 $^{\mathrm{y}}$ & $1.2 \mathrm{~d}$ & $2.2 \mathrm{c}$ & $3.1 \mathrm{~b}$ & $3.8 \mathrm{a}$ \\
DSI 4 & $1.2 \mathrm{c}$ & $2.2 \mathrm{~b}$ & $2.8 \mathrm{~b}$ & $3.7 \mathrm{a}$ \\
Root fresh weight (g) & $44.5 \mathrm{a}$ & $32.2 \mathrm{~b}$ & $31.0 \mathrm{~b}$ & $29.6 \mathrm{~b}$ \\
Root necrosis (\%) & $48 \mathrm{~b}$ & $72 \mathrm{a}$ & $79 \mathrm{a}$ & $89 \mathrm{a}$ \\
Height growth $(\mathrm{cm})^{\mathrm{x}}$ & $0.2 \mathrm{a}$ & $-0.9 \mathrm{a}$ & $-2.3 \mathrm{a}$ & $-2.0 \mathrm{a}$ \\
Diameter growth $(\mathrm{mm})_{\mathrm{P}_{\mathrm{n}} \mathrm{fl}^{\mathrm{w}}}$ & $0.6 \mathrm{a}$ & $0.18 \mathrm{a}$ & $0.08 \mathrm{a}$ & $0.11 \mathrm{a}$ \\
$\mathrm{P}_{\mathrm{n}} 1^{\mathrm{w}}$ & $8.1 \mathrm{a}$ & $2.09 \mathrm{~b}(25.8)$ & $3.54 \mathrm{~b}(43.6)$ & $1.58 \mathrm{~b}(19.5)$ \\
$\mathrm{P}_{\mathrm{n}} 2^{\mathrm{w}}$ & $10.49 \mathrm{a}$ & $5.90 \mathrm{~b}(56.2)$ & $3.22 \mathrm{c}(30.7)$ & $0.45 \mathrm{~d}(4.3)$ \\
\hline
\end{tabular}

${ }^{2}$ Mean separation within each response variable at $P \leq 0.05$; variables listed only if the $\mathrm{F}$ test was significant. ${ }^{y}$ Disease severity index (DSI) 1, 2, and 4 weeks after the onset of flooding; $1=$ asymptomatic, $4=$ complete defoliation or leaf necrosis.

xPlants with symptoms frequently had curled, dried shoots resulting in an apparent decrease in height. ${ }^{w}$ Net photosynthesis $\left(\mu \mathrm{mol} \cdot \mathrm{m}^{-2} \cdot \mathrm{s}^{-1}\right)$ during the flooding period, and 1 and 2 weeks after flooding ended. In parentheses, $\mathrm{P}_{\mathrm{n}}$ as a percentage of the control.

good performance of this taxon in our study probably reflects the mild flooding treatment, but the results also imply that of the taxa tested, most are more susceptible to flooding injury and root rot than $P$. mahaleb.

Prunus yedoensis had the third highest survival rate across all treatments and $80 \%$ survival in the combination treatment. The taxon also had a low DSI and low defoliation and root necrosis percentages, suggesting it was one of the more flood- and root rottolerant taxa. In a preliminary flooding study, another population of $P$. yedoensis had the highest survival rate (29\%) of several Prunus taxa. The taxon also performs well as a mature tree in compacted, wet soils in the Washington, D.C., area, albeit it is often grafted on $P$. avium. These data warrant further evaluation of $P$. yedoensis for tolerance to flooding and root rot.

Significant differences in $\mathrm{P}_{\mathrm{n}}$ were detected between treatments, but not between taxa. The combination treatment caused the greatest drop in $\mathrm{P}_{\mathrm{n}}$, to $12.4 \%$ of the control by the end of the experiment, compared to $35.8 \%$ of the control for flooded plants and $64.5 \%$ of the control in pathogen-treated plants (Table 2). The variation in $\mathrm{P}_{\mathrm{n}}$ within a given taxon was substantial owing to three factors: diverse, nonclonal germplasm; variable, natural light conditions; and a small sample size for each taxon. Plants were derived from open-pollinated seed collected at the National Arboretum in most cases. The seedlings of $P$. mahale $b$ and $P$. sargentii were obtained from commercial sources and also were likely to have been grown from openpollinated seed. Other studies using more uniform plant material and controlled, supplemental lighting found $\mathrm{P}_{\mathrm{n}}$ to be a useful indicator of variation in flood tolerance among Prunus taxa (Beckman et al., 1992; Ranney, 1994).

The rate of recovery of photosynthesis after a flooding event may indicate tolerance to flooding in trees (Kozlowski, 1984). Although no significant differences in $\mathrm{P}_{\mathrm{n}}$ values were detected between taxa, speed of $P_{n}$ recovery differed among taxa in the flooded and pathogen treatments. Net $P_{n}$ did not recover in any taxon in the combination treatment. The $\mathrm{P}_{\mathrm{n}}$ of two taxa recovered in the flooded treatment: $\mathrm{P}_{\mathrm{n}}$ of $P$. sargentii had increased to $83 \%$ of the control and that of $P$. veracunda to $50 \%$ of the control 3 weeks after flooding (Table 4). Net photosynthesis of one taxon, P. yedoensis, remained stable in the flooded treatment, and all remaining taxa sustained a reduced $\mathrm{P}_{\mathrm{n}}$ for the duration of the study. These data, and the fact that the final $P_{n}$ in the flooded treatment varied considerably between taxa (Table 4), suggest that some variation in flood tolerance exists between the taxa.
The pathogen treatment caused an early decline in $\mathrm{P}_{\mathrm{n}}$ in most taxa, but within 2 weeks, $\mathrm{P}_{\mathrm{n}}$ rose to between $69 \%$ and $118 \%$ of the controls in all but $P$. sargentii (Table 4). Prunus sargentii regained only $50 \%$ of its photosynthetic capability in the pathogen treatment. Prunus sargentii also had the lowest survival rate, the most defoliation, and the highest DSI in the pathogen treatment (data not shown), suggesting that it may be more susceptible to P. cryptogea than the other taxa.

Our results are the first to demonstrate that some ornamental Prunus taxa are susceptible to $P$. cryptogea and that an additive effect occurs when flooding is combined with exposure to $P$. cryptogea. The fact that most taxa were not seriously affected by the pathogen in the absence of flooding suggests that phytophthora root rot in the field could be minimized by preventing flooding injury. Evaluation of the taxa using other Phytophthora spp. is needed since more than one Phytophthora spp. are frequently present in field situations. Although survival, $\mathrm{P}_{\mathrm{n}}$, defoliation, and DSI values indicated variation between taxa in tolerance to flooding and root rot, the ranking of taxa was not always consistent. Survival following cold storage was not directly associated with any other plant response. Comparisons of the taxa, especially $P$. takesimensis and $P$. yedoensis, using uniform seed sources and plant material, will help to evaluate tolerance to flooding and root rot and clarify the relationship between survival and other host responses.

\section{Literature Cited}

Beckman, T.G., R.L. Perry, and J.A. Flore. 1992. Short-term flooding affects gas exchange characteristics of containerized sour cherry trees. HortScience 27:1297-1301.

Frye, J. and W. Grosse. 1992. Growth responses to flooding and recovery of deciduous trees. $\mathrm{Z}$. Naturforsch. 47c:683-689.

Kannwisher, M.I. and D.J. Mitchell. 1978. The influence of a fungicide on the epidemiology of black shank of tobacco. Phytopathology 68:1760-1765.

Kawase, M. 1981. Anatomical and morphological adaptation of plants to waterlogging injuries. HortScience 19:8-12.

Kozlowski, T.T. 1984. Responses of woody plants to flooding, p. 129-163 In: T.T. Kozlowski

Table 3. Average response of Prunus taxa across all treatments, listed in order of decreasing survival. ${ }^{2}$

\begin{tabular}{|c|c|c|c|c|c|c|c|c|c|c|}
\hline \multirow[b]{3}{*}{ Taxon } & \multicolumn{10}{|c|}{ Response variable } \\
\hline & \multirow[b]{2}{*}{$\begin{array}{l}\text { Survival } \\
(\%)\end{array}$} & \multirow[b]{2}{*}{$\begin{array}{l}\text { Initial ht } \\
(\mathrm{cm})\end{array}$} & \multirow[b]{2}{*}{$\begin{array}{l}\text { Defolia- } \\
\text { tion }(\%)\end{array}$} & \multirow[b]{2}{*}{$P_{n} 1^{y}$} & \multirow[b]{2}{*}{ DSI $1^{x}$} & \multirow[b]{2}{*}{ DSI $2^{x}$} & \multirow[b]{2}{*}{ DSI $4^{x}$} & \multicolumn{2}{|c|}{ Root } & \multirow{2}{*}{$\begin{array}{l}\mathrm{Ht} \\
\text { growth } \\
(\mathrm{cm})^{\mathrm{w}}\end{array}$} \\
\hline & & & & & & & & $\begin{array}{l}\text { Necrosis } \\
(\%)\end{array}$ & $\begin{array}{l}\text { Wt } \\
(\mathrm{g})\end{array}$ & \\
\hline P. takesimensis & $100 \mathrm{a}$ & $52.0 \mathrm{bc}$ & $68 \mathrm{ab}$ & $3.22 \mathrm{~d}$ & $2.9 \mathrm{ab}$ & $2.1 \mathrm{~d}$ & No data & $77 \mathrm{ab}$ & $103.4 \mathrm{a}$ & $-2.6 \mathrm{~b}$ \\
\hline P. mahaleb & $91 \mathrm{ab}$ & $74.2 \mathrm{ab}$ & $49 \mathrm{~d}$ & $7.14 \mathrm{a}$ & $2.2 \mathrm{c}$ & $2.4 \mathrm{~b}-\mathrm{d}$ & $2.2 \mathrm{c}$ & $92 \mathrm{ab}$ & $57.7 \mathrm{~b}$ & $3.2 \mathrm{a}$ \\
\hline $\begin{array}{l}P . \text { yedoensis } \\
P \text {. incisa } \times P \text {. 'Kursar', }\end{array}$ & $89 \mathrm{ab}$ & $42.9 \mathrm{c}$ & $53 \mathrm{~cd}$ & $5.83 \mathrm{a}-\mathrm{c}$ & $2.4 \mathrm{c}$ & $2.3 \mathrm{~cd}$ & $2.2 \mathrm{c}$ & $63 c$ & $26.6 \mathrm{c}$ & $-2.0 \mathrm{~b}$ \\
\hline $\begin{array}{l}\text { HY } 5118 \\
P \text {. 'Okame' } \times \text { P. campanulata }\end{array}$ & $84 \mathrm{~b}$ & $40.7 \mathrm{c}$ & $61 \mathrm{bc}$ & $4.69 \mathrm{~cd}$ & $2.7 \mathrm{ab}$ & $2.6 \mathrm{a}-\mathrm{c}$ & $2.5 \mathrm{bc}$ & $74 \mathrm{ab}$ & $22.4 \mathrm{c}$ & $-2.1 \mathrm{~b}$ \\
\hline HY 5111 & $83 \mathrm{~b}$ & $27.2 \mathrm{c}$ & $50 \mathrm{~cd}$ & $6.86 \mathrm{ab}$ & $2.6 \mathrm{~b}$ & $2.5 \mathrm{~b}-\mathrm{d}$ & $2.3 \mathrm{bc}$ & $75 \mathrm{ab}$ & $12.2 \mathrm{c}$ & $-1.2 \mathrm{~b}$ \\
\hline P. incisa & $82 \mathrm{~b}$ & $30.9 \mathrm{c}$ & $53 \mathrm{~cd}$ & $5.05 \mathrm{~b}-\mathrm{d}$ & $2.7 \mathrm{ab}$ & $2.7 \mathrm{ab}$ & $2.7 \mathrm{ab}$ & $72 \mathrm{bc}$ & $15.0 \mathrm{c}$ & $-2.3 \mathrm{~b}$ \\
\hline P. veracunda & $82 \mathrm{~b}$ & $35.0 \mathrm{c}$ & $54 \mathrm{~cd}$ & $4.10 \mathrm{~cd}$ & $2.6 \mathrm{~b}$ & $2.6 \mathrm{a}-\mathrm{c}$ & $2.5 \mathrm{bc}$ & $70 \mathrm{bc}$ & $21.7 \mathrm{c}$ & $-2.5 \mathrm{~b}$ \\
\hline P. sargentii & $81 \mathrm{~b}$ & $78.3 \mathrm{a}$ & $73 \mathrm{a}$ & $4.15 \mathrm{~cd}$ & $2.9 \mathrm{a}$ & $2.9 \mathrm{a}$ & $3.0 \mathrm{a}$ & $82 \mathrm{a}$ & $59.4 \mathrm{~b}$ & $-1.2 \mathrm{~b}$ \\
\hline
\end{tabular}

${ }^{2}$ Mean separation between taxa at $P \leq 0.10$; response variables are listed only if the analysis of variance indicated a significant taxon effect at $P \leq 0.05$.

${ }^{y}$ Net photosynthesis $\left(\mu \mathrm{mol} \cdot \mathrm{m}^{-2} \cdot \mathrm{s}^{-1}\right) 1$ week after flooding ended.

${ }^{x}$ Disease severity index (DSI) 1, 2, and 4 weeks after the onset of flooding; $1=$ asymptomatic, $4=$ complete defoliation or leaf necrosis.

wPlants with symptoms frequently had curled, dried shoots resulting in an apparent decrease in height. 
Table 4. Net photosynthesis of Prunus taxa during and after flooding as percentage of control and, in parentheses, actual $\left(\mathrm{P}_{\mathrm{n}}\right)$ values for controls. Each value is the mean of six plants (one leaf per plant).

\begin{tabular}{|c|c|c|c|c|c|c|}
\hline \multirow[b]{3}{*}{ Taxon } & \multirow[b]{3}{*}{ Treatment } & \multicolumn{5}{|c|}{ Net photosynthesis $\left[\%\right.$ of control $\left(\right.$ control in $\left.\left.\mu \mathrm{mol} \cdot \mathrm{m}^{-2} \cdot \mathrm{s}^{-1}\right)\right]$} \\
\hline & & \multicolumn{5}{|c|}{ Time in relation to flooding } \\
\hline & & During & $+1-2$ days & +1 week & +2 weeks & +3 weeks \\
\hline \multirow[t]{3}{*}{ P. mahaleb } & Flooded & $34(12.74)$ & $17(11.80)$ & 35 (14.39) & $35(10.18)$ & $19(10.15)$ \\
\hline & Phytophthora & 25 & 51 & 63 & 118 & 81 \\
\hline & Combined & 17 & 15 & 5 & 10 & 9 \\
\hline \multirow[t]{3}{*}{ P. sargentii } & Flooded & $26(7.00)$ & $22(7.87)$ & $38(8.48)$ & $43(9.63)$ & $83(8.38)$ \\
\hline & Phytophthora & 9 & 56 & 43 & 46 & 47 \\
\hline & Combined & 16 & 7 & 0 & 0 & 7 \\
\hline \multirow[t]{3}{*}{ P. yedoensis } & Flooded & $51(9.14)$ & $50(10.31)$ & 47 (10.79) & $56(10.29)$ & $52(11.48)$ \\
\hline & Phytophthora & 33 & 44 & 69 & 86 & 67 \\
\hline & Combined & 21 & 5 & 2 & 21 & 23 \\
\hline \multirow[t]{3}{*}{ P. takesimensis ${ }^{\mathrm{z}}$} & Flooded & $22(3.98)$ & $1(6.68)$ & $6(8.86)$ & $18(4.82)$ & $0(5.82)$ \\
\hline & Phytophthora & 11 & 5 & 22 & 89 & 0 \\
\hline & Combined & 17 & 2 & 1 & 0 & 0 \\
\hline \multirow[t]{3}{*}{ P. verecunda } & Flooded & $51(5.95)$ & $16(9.01)$ & $16(10.44)$ & $28(9.53)$ & $50(10.75)$ \\
\hline & Phytophthora & 28 & 19 & 37 & 69 & 86 \\
\hline & Combined & 27 & 8 & 7 & 8 & 17 \\
\hline \multirow[t]{3}{*}{ P. incisa } & Flooded & $66(8.77)$ & $39(9.54)$ & $16(11.14)$ & $23(10.76)$ & $31(9.59)$ \\
\hline & Phytophthora & 21 & 43 & 69 & 70 & 86 \\
\hline & Combined & 31 & 5 & 1 & 15 & 12 \\
\hline \multicolumn{7}{|l|}{ P. incisa $\mathrm{X}$} \\
\hline \multirow[t]{3}{*}{ (HY 5118) } & Flooded & $71(4.19)$ & $15(8.61)$ & $52(9.05)$ & $48(9.29)$ & $38(7.77)$ \\
\hline & Phytophthora & 53 & 25 & 71 & 90 & 68 \\
\hline & Combined & 43 & 13 & 1 & 0 & 12 \\
\hline \multicolumn{7}{|l|}{ P. 'Okame' $\mathrm{x}$} \\
\hline$($ HY5111) & Flooded & $35(11.93)$ & $19(8.80)$ & $40(12.44)$ & $0(9.85)$ & $0(10.59)$ \\
\hline & Phytophthora & 31 & 39 & 65 & 105 & 21 \\
\hline & Combined & 16 & 2 & 18 & 39 & 0 \\
\hline
\end{tabular}

${ }^{\mathrm{z}}$ Prunus takesimensis was evaluated in first trial only.

${ }^{\mathrm{y}} \mathrm{HY} 5111$ was evaluated in first and second trials only. (ed.). Flooding and plant growth. Academic, Orlando, Fla.

Mircetich, S.M. and M.E. Matheron. 1976. Phytophthora root and crown rot of cherry trees. Phytopathology 66:549-558.

Mizutani, F.M., M. Yamada, A. Suguira, and T. Tomana. 1979. Differential water tolerance among Prunus species and the effects of waterlogging on the growth of peach scions on various rootstocks. Stud. Inst. Hort. Kyoto Univ. 9:28-35.

Ranney, T.G. 1994. Differential tolerance of eleven Prunus taxa to root zone flooding. J. Environ. Hort. 12:138-141.

Rowe, R.N. and D.V. Beardsell. 1973. Waterlogging of fruit trees. Hort. Abstr. 43:553-548.

Rowe, R.N. and P.B. Catlin. 1971. Differential sensitivity to waterlogging and cyanogenesis by peach, apricot, and plum roots. J. Amer. Soc. Hort. Sci. 96:305-308.

SAS Institute. 1990. SAS/STAT user's guide (version 6, 4th ed.). SAS Inst., Cary, N.C.

Stolzy, L.H. and R.E. Sojka. 1984. Effects of flooding on plant disease, p. 221-264. In: T.T. Kozlowski (ed.). Flooding and plant growth. Academic, Orlando, Fla.

Wicks, T. and T.C. Lee. 1985. Effects of flooding, rootstocks and fungicides on phytophthora crown rot of almonds. Austr. J. Expt. Agr. 25:705-710.

Wilcox, W.F. and S.M. Mircetich. 1985a. Effects of flooding duration on the development of phytophthora root and crown rots of cherry. Phytopathology 75:1451-1455.

Wilcox, W.F. and S.M. Mircetich. 1985b. Pathogenicity and relative virulence of seven Phytophthora spp. on Mahaleb and Mazzard cherry. Phytopathology 75:221-226. 